\title{
МОБІЛЬНІ ТЕХНОЛОГІЇ ТА СУЧАСНИЙ МЕДІАТЕКСТ
}

\author{
Галина Синоруб \\ Тернопільський національний педагогічний університет імені Володимира Гнатюка \\ вул. Максима Кривоноса, 2, 46027, Тернопіль, Україна \\ e-mail: sunoryb@ukr.net \\ https://orcid.org/0000-0001-7073-0752
}

Проаналізовано особливості використання мобільних технологій в медіадіяльності. Визначено основні формати та жанри, що використовуються в мобільній журналістиці. За результатами емпіричного дослідження виокремлено основні переваги й недоліки мобільної журналістики та окреслено перспективи її розвитку.

Ключові слова: мобільна журналістика, медіа, МоЈо, мобільні технології, мобільний телефон, інтернет.

Постановка проблеми. Журналістика є однією із сфер, що піддається трансформації під впливом сучасних технологій. Успіх теперішніх медіа залежить не стільки від самого контенту, скільки від того, в якому форматі його отримає споживач, на якій інформаційній платформі опублікує та наскільки актуальним й швидким буде подання інформації. Цим процесам сприяє використання мобільних технологій, що забезпечують оперативність та інтерактивність у комунікаційному процесі «медіа - аудиторія».

Попри відносну новизну поняття мобільної журналістики, все більше зарубіжних та українських учених зосереджує увагу на особливостях, можливостях та перспективі її використання. Так, конструювання гіперлокальних медіа засобами мобільних технологій досліджував доцент кафедри комунікації Гавайського університету в Манао (США) Б. Оппегаард. На перевагах та недоліках використання мобільних технологій у журналістській діяльності зосередив свою увагу чеський науковець Франшек Гел (Фейгел). Розвиток мобільної журналістики та особливості їі функціонування досліджували учені: Д. Кемерон із університету Ньюкасла (США), М. Сільва Палаціос та С. Барбоза із Федерального університету штату Баїя (Бразилія) та ін.

У 2015 р. у Дубліні (Ірландія) відбулася Перша міжнародна конференція із мобільної журналістики «MoJoCon», за підсумками якої було виголошено потреби в інституціоналізації мобільної журналістики, необхідність вивчення мобільного медіамаркетингу, перспективність різних операційних систем для роботи на персональних гаджетах, збільшення кількості годин онлайнового мовлення, орієнтація на мобільний аудіовізуальний контент навіть великих медіакомпаній тощо [1, с. 256].

(с) Синоруб Г., 2019 
Серед українських учених нові можливості мобільної журналістики в медіа досліджували: А. Баклан, О. Коструба, В. Рябічев та ін. Проте, в науковій літературі майже нема праць із вивчення можливостей сучасних мобільних технологій, дослідження їх ролі у творенні сучасного медіатексту, що і зумовлює актуальність даного дослідження.

Мета даної роботи полягає у виявленні особливостей, можливостей та частоти використання мобільної журналістики у сучасному медіапросторі.

Відповідно до мети, поставлені такі завдання: окреслити технологічний розвиток та можливості мобільних пристроїв, охарактеризувати мобільні додатки, за допомогою яких можна створювати якісний медіаконтент та розміщувати його на різних інформаційних платформах, визначити переваги й недоліки мобільної журналістики.

Сучасний ринок мобільних пристроїв відзначається жорсткою конкуренцією операційних систем: Andriod, iOS, Windows Phone, Java Me, Simbian, Black-Berry, Samsung та ін., що постійно працюють над вдосконаленням програмного забезпечення [2]. Технології швидкісного мобільного зв'язку перетворили кожен пристрій в повноцінну мультимедійну систему, яка використовується, як на етапі збору та фіксації інформації (текст, аудіо, відео, фото), її обробки (графічні редактори, монтажні столи тощо) так і на передачі презентації (електронна пошта, телефонний зв'язок, месенджери, постинг у соціальних мережах, програми-агрегатори конкретних радіопроектів).

Мобільна журналістика в Україні почала активно розвиватися в період Революції гідності 2014 р. Стріми стали чи не головним механізмом документування суспільно-політичних подій. Крім цього, мобільні технології створили можливості для розвитку якісної громадянської журналістики. Так, у мережі «Global voices», яка об'єднує медіа із 167 країн почало з'являтись відчутно більше відеоматеріалів. Очевидно, що більшу частину з них відзнято на мобільні пристрої» [2].

У період трансформацій відбулися зміни і в жанристиці медіа. Характерними в мобільній журналістиці є такі нові жанри: веб-огляд, веб-новина, онлайн-хроніка, онлайн-репортаж (стрім), стрічка заголовків, мультимедійна стаття, моблог - блог, створений за допомогою мобільного чи іншого портативного технічного засобу. Моблог ідеально підійде для таких подій як: масові політичні акції, вибори, стихійні лиха, війни, концерти на відкритих майданчиках, фестивалі далеко від міст, масштабні святкування тощо.

Сучасні мобільні пристрої містять мобільні додатки, які є доступними для користування в роботі журналіста. Розглянемо програми, якими може скористатись медійник для створення медіаконтенту. Для відеопродукту може підійти PicPlayPost - мобільний додаток для створення відеоколажів. Дозволяє додавати музику та завантажувати готовий матеріал на Facebook, Vine та Instagram; ThingLink програма, яка дозволяє зробити відео та фото більш інтерактивним. Vine - програма для створення інтерактивних коротких відео з ефектом руху, Bambuser, Periscope дозволяють стрімити 3 мобільного телефона будь-де і в будь-який час за наявності доступу до інтернету [3].

Без сумніву, фоторепортаж, фотозвіт, фотослайд шоу є популярними жанрами серед аудиторії. Instagram - мобільний додаток для поширення фото, що дозволяє також редагувати фото безпосередньо перед завантаженням; Picmonkey - онлайновий фоторедактор, що дозволяє створювати колажі та історії з елементами дизайну; Snapseed - дає можливість працювати з фотографіями безпосередньо на мобільному 
телефоні та застосовувати велику кількість інструментів редагування: яскравість, контраст, насиченість, тіні, світло, тепло тощо; Legend - мобільний додаток для створення рухомих картинок із текстом; TheNounProject - сайт для завантаження ілюстрацій, іконок, ескізів, символів тощо» [4].

Перший редактор iPad-версії the Wall Street Journal Девід Гоу (David Но), якого вважають найбільш досвідченим редактором новинних мобільних додатків у світі, визначив топ додатків, які значно покращать та полегшать роботу мобільного журналіста: Cogi - накопичує аудіо та підтримує додавання нотаток; iTranslate ефективний інструмент для перекладу; CamScanner перетворює телефон на сканер; Audio Memos - диктофон на стероїдах; Speaking Photo накладає голос до фотографій; Meerkat - новий стандарт стрімінгу; Ban.jo - організовує та аналізує соціальні медіа за місцезнаходженням; Pocket зберігає інформацію для пізнішого читання; Life 360 - чудовий інструмент для організовування репортерів у полі» [5].

Результати дослідження. 3 метою вивчення ролі мобільних телефонів у професійній діяльності медійника, було проведено опитування серед практикуючих журналістів м. Тернополя щодо використання мобільних пристроїв під час роботи.

Було опитано 63 журналістів, що представляють різні медіа Тернополя. Вік опитаних становить: до 18 років - 5\%, від 18 до 25 років - 55\%, від 25 до 45 - 40\%.

Досвід роботи в журналістиці: до 1 року - 15\%, від 1 до 2 років - 15\%, від 2 до 3 років - 35\%, від 5 до 10 років - 25\%, більше 10 років - 10\% (Рис. 1).

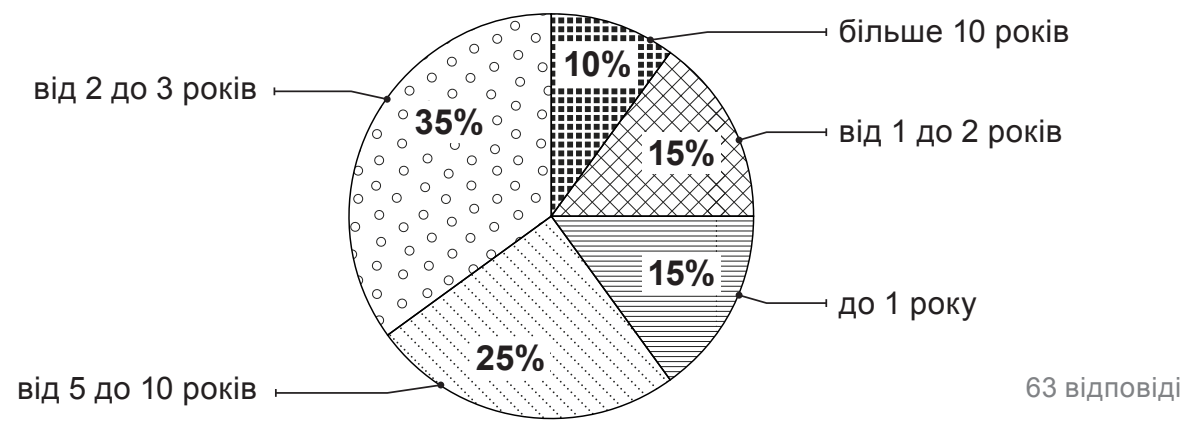

Рис. 1. Досвід роботи в журналістищуі

На запитання 2 (Рис. 2) 90,9\% медійників користуються мобільними пристроями для збору, підготовки та передачі інформації під час виконання журналістського завдання, 9,1\% їх не використовують.

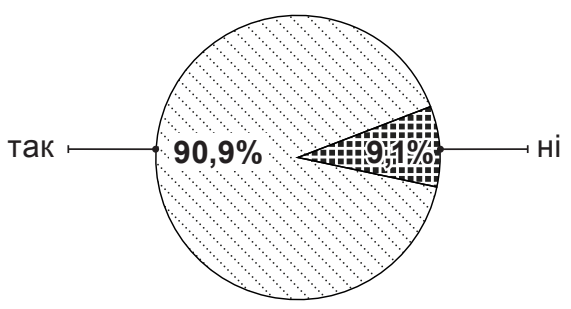

63 відповіді

Рис. 2. Використання мобільних телефонів у журналістській діяльності 
Результати свідчать про те, що мобільні телефони стали зручними помічниками в журналістській діяльності та незалежно від медіа, в якому працює журналіст, широко використовуються поряд із іншими професійними технічними пристроями. Так, серед опитаних журналістів, що використовують мобільний пристрій під час роботи, більше половини є представниками інтернет-видань (65\%). Журналісти, що працюють на двох інформаційних платформах - інтернет-виданні та друкованій газеті, - становить $10 \%$, на телебаченні - $20 \%$ від опитаних, у газетах і журналах становить 5\% респондентів (Рис. 3). Таким чином, журналісти інтернет-медіа $є$ найчисельнішою групою опитаних.

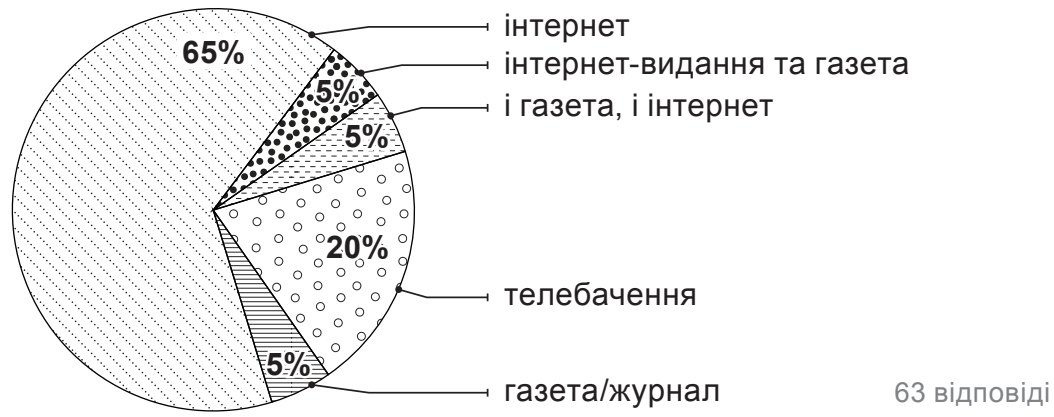

Рис. 3. Медіа, в яких праиюють журналісти

Оскільки практично всі традиційні медіа мають інтернет-версію, постало питання оптимізації інтернет-видань, що сприятиме збільшенню аудиторії та зростанню довіри до медіа. У зв’язку з тим, що інтернет є одним із найактивніших та найпопулярніших засобів передачі та обміну інформації, майже всі опитані підтвердили наявність інтернет-сторінки (сайту) свого медіа, із яких 75\% мають мобільні версії та 5\% - планує оптимізувати свою інтернет-платформу в найближчому часі. Відповідно, 20\% опитаних журналістів вказали про відсутність оптимізації інтернет-медіа під мобільні пристрої (Рис. 4).

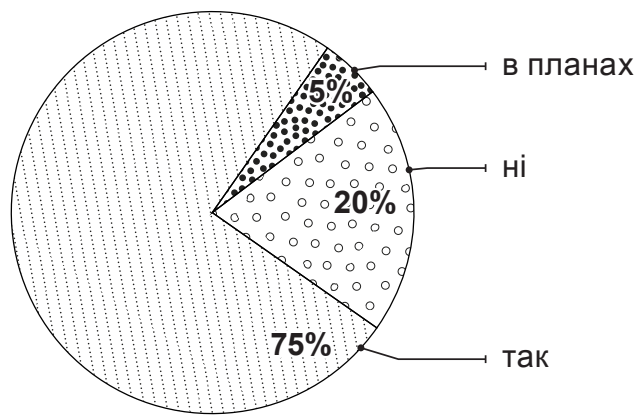

Рис. 4. Наявність мобільної версї медіа 
Сучасні мобільні телефони мають значну кількість функцій, які практикуючий журналіст може використовувати під час своєї професійної діяльності. Створення фотографій, запис аудіо та відео, їх обробка, написання тексту та передача його на інші носії інформації $є$ неповним переліком можливостей мобільного телефону, які журналіст може використовувати. Проводячи опитування, ми дослідили, які можливості гаджету найбільше використовують журналісти у своїй роботі. Таким чином, $45 \%$ із опитаних використовують свій мобільний пристрій для фотографування. Невеликі камери в мобільному телефоні сьогодні достатньо потужні, щоб робити відносно якісні, «живі» фотографії з місця події. Наступною за популярністю функцію, що використовують журналісти є аудіозапис (20\%). 15\% респондентів використовують мобільний пристрій для написання тексту. Зазначені функції допомагають передати інформацію максимально оперативно та економить час самого журналіста. Медійників, які найчастіше використовують мобільні пристрої для відеозапиcy, $-10 \%$. Такий невисокий рівень популярності мобільного відеозапису може бути пов'язаний із усе ще невисокою якістю відео в порівнянні з професійною камерою та оператором, проте мобільне відео більш оперативне та зручніше у використанні. Журналісти, які часто використовують усі з вище перерахованих можливостей мобільного телефону, становить 10\% (Рис. 5.).

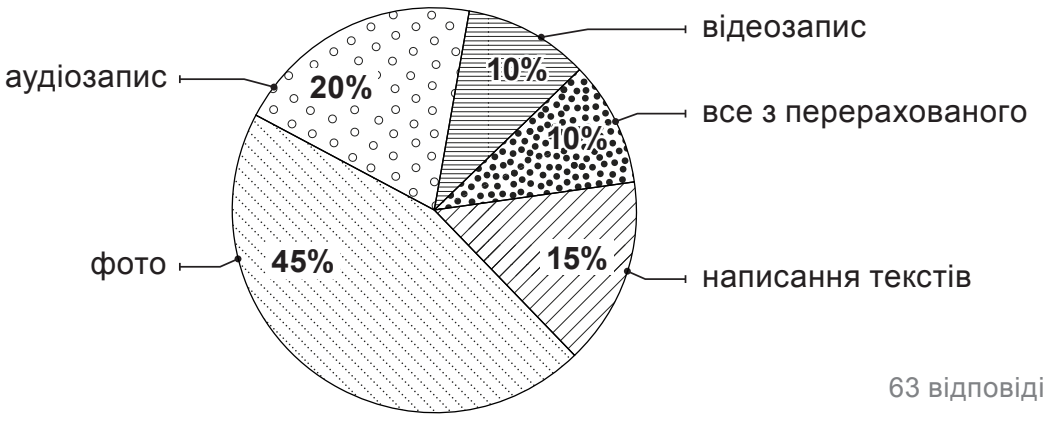

Рис. 5. Найбільш популярні формати в мобільній журналістиці

Крім можливостей самого мобільного телефона, існують безліч додатків, що покращують та пришвидшують роботу медійника. Так, досліджуючи популярні додатки серед журналістів, 3'ясовано, що $84.2 \%$ із опитаних використовують додаток Camera, який дозволяє робити фотографії та їх редагувати. Rode Record - другий за популярністю додаток, який використовують $36.8 \%$ респондентів, та призначений для запису, редагування та публікації звуку.

Популярним серед журналістів $є$ додатки для монтажу відео такі як iMovie $(15.8 \%)$, Kinemaster (5.3\%), якими зручно користуватись як і початківцю, так і професійному користувачу.

Деякі журналісти також використовують додатки для зберігання інформації на своєму пристрої, наприклад, Airstash, що є розширеною альтернативою вбудованого веб-інтерфейсу із додатковими функціями. Його використають 5.3\% опитаних журналістів (Рис. 6). 
Якими додатками мобільних телефонів Ви найчастіше користуєтесь у журналістській професії? (можна вибрати кілька варіантів)

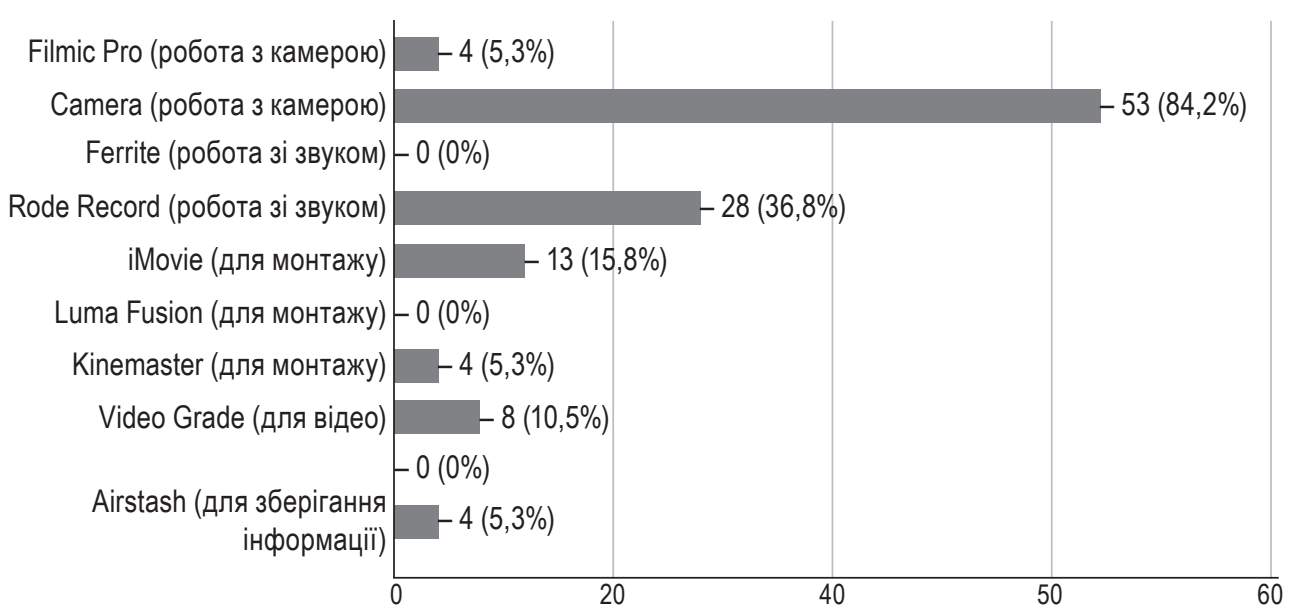

Рис. б. Рейтинг популярності мобільних додатків

Для того, щоб з'ясувати, наскільки зручно медійникам використовувати мобільні телефони в роботі, респондентам запропоновано дати оцінку за 10 -бальною шкалою. Таким чином, $30 \%$ журналістів оцінили зручність на 7 балів, $20 \%$ на 10 , по 6, 8 і 9 балів оцінила однакова кількість опитаних, що становить 15\% на кожну відповідь і тільки 5\% журналістів. 5\% - загальна зручність користування мобільними телефонами під час виконання журналістського завдання визначає як вище середнього (Рис. 7).

Оцініть зручність використання мобільних телефонів для підготовки інформації

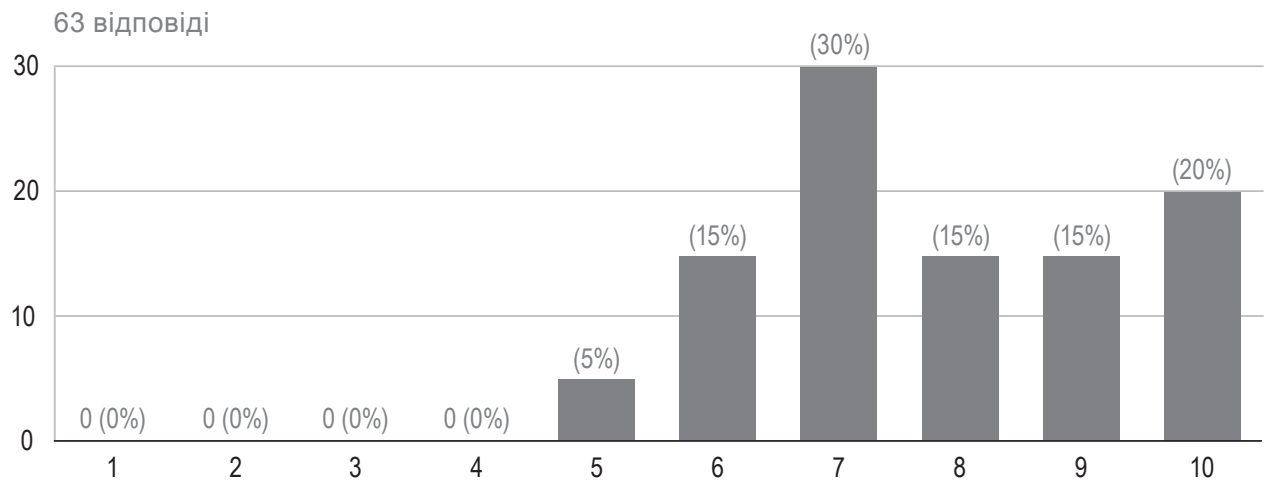

Рис. 7. Зручність використання мобільних телефонів у створенні медіатексту 
Отже, опитавши 63 практикуючих журналістів із різних видів медіа, із різним досвідом роботи та віком, визначено, що більшість із них $-90.9 \%$ використовують мобільні телефони під час професійної діяльності, а медіа, які вони представляють, мають або планують створити мобільну версію та становлять $80 \%$ від загальної кількості опитаних. Такий показник дає поштовх до виокремлення основних переваг мобільних пристроїв в роботі журналіста, якими є: висока мобільність, можливість залишатися непомітним, доступність та легкість застосування геотегів, оперативність передачі відзнятого контенту та стрімкий розвиток технологій, які використовуються для зйомки та відеозапису.

Проте, поряд із перевагами, мають місце й певні мінуси: відсутність або значна обмеженість оптичного зуму, порівняно повільна система фокусування та граничне значення витримки, низька якість світлин та відео, тощо.

Таким чином, мобільні пристрої розширили можливості для журналістів працювати і звітувати з місця події, не використовуючи професійної техніки. Перспектива подальших досліджень полягає в систематичному вивченні інтернет-доступу та функціоналу розширеного пошуку разом із безліччю інтелектуальних та легкодоступних додатків, що забезпечуватиме журналістів новими та потужними інструментами для подачі новини з використанням мінімального терміну часу.

\section{REFERENCES}

1. Гиріна Т. С. Реконфігурація медіаресурсів у процесі створення мобільної радіожурналістики. Запоріжжя, 2017. С. 251-263.

2. Журналістика для всіх. [Електронний ресурс]. Режим доступу до ресурсу: http:// sumynews.com/pro-tsentr/8307/mobilna-zhurnalistyka-novi-mozhlyvosti.html

3. Піддубний О. Об’єктивний світ медіа. [Електронний ресурс]. Режим доступу до pecypcy: http://piddubny.com/objektyvnyj-svit-media/

4. Пять инструментов, которые журналисты могут использовать для потоковой трансляции видео // Редакторский портал. 2015. [Електронний ресурс]. Режим доступу до ресурсу: http://redactor.in.ua/ru/practice/7078.Pyat-instrumentov-kotoriezhurnalisti-mogut-ispolzovat-dlya-potokovoy-translyatsii-video

5. European Journalism Observatory. 10 додатків, що відразу покращать мобільну роботу журналіста. [Електронний ресурс]. Режим доступу до ресурсу: ua.ejo-online. eu/2418/tsyfrovi-media/10-додатків-що-відразу-покращать-мобіл 


\title{
MOBILE TECHNOLOGIES AND MODERN MEDIA TEXT
}

\author{
Halyna Synorub \\ Ternopil Volodymyr Hnatiuk National Pedagogical University \\ 2 Maxyma Kryvonosa str., 46027, Ternopil, Ukraine \\ e-mail: sunoryb@ukr.net \\ https://orcid.org/0000-0001-7073-0752
}

There are analyzed features of using digital technologies in media activity. There is payed attention on importance of efficiency and interactivity in communicative process that called "media audience". It is considered scientific approaches of foreign and Ukrainian scientists about features, opportunities and perspectives of using mobile technologies in journalists' work. It is outlined technologies of high-speed mobile communications, there were considered their influence on the transformation of devices into a full multimedia system that used not only at the stage of gathering and fixing information (text, audio, video, photo), its processing (graphic editors, assembly tables, etc.) and on ways of presentations transfer (e-mail, telephone communication, messengers, posting in social networks, program-aggregators of specific radio projects). There is focused attention on the mobile applications using and quality media content creation. There are defined basic formats and genres that are used in mobile journalism. There are analyzed features of civil journalism. There are selected mobile applications that are easy in using in work of journalist. There are identified top apps, which make easier and better work of mobile journalists. There are determinated main possibilities of mobile technologies and possible challenges of mobile journalism. It is proved that using of smartphones and tablets in the professional activity of a modern journalist gradually shifts from the zone of constraints to the area of opportunity. According to the results of the empirical research, there are outlined main advantages and disadvantages of mobile journalism are outlined and the prospects for its development. There is payed attention on the fact that mobile journalism provides the opportunity to creatin and using different content, promotes interactivity and sharing information to various information platforms.

Key words: mobile journalism, media, Mojo, mobile technologies, mobile phone, internet. 